IJ§ER

ISSN: 2149-5939
International Journal of Social Sciences and Education Research

Online, http://dergipark.gov.tr/ijsser

Volume: 2(1), 2016

\title{
A study for the evaluation of entrepreneurship level of fourth grade stu- dents in Recreation and Sports Management Department
}

\author{
Çiğdem Bacak ${ }^{1} \quad$ Oğuzhan Dalkıran ${ }^{2}$
}

Received Date: $21 / 10 / 2015$

Accepted Date: 30/ $12 / 2015$

\begin{abstract}
The main purpose of this study is to determine the differences between the entrepreneurship levels of the Sport Management and Recreation the fourth year students who are enrolled in the recreation programs of universities. The sample of this investigation consists 268 students studying in the recreation departments of Erciyes, Kocaeli, Sakarya, Muğla, Akdeniz and Pamukkale Universities during the spring semester of 2014-2015 academic year. To determine the difference between entrepreneurship levels of sample group is used "Entrepreneurship Scale for the University Students' developed by Yilmaz and Sünbül '(2009) and to determine the demographic features of students "is used "Personal Information Form" created by the researcher. In the analysis of personal information form data is used frequency and percentage distribution. Non-parametric tests were applied because of the data were not realize normal distribution. To analysis of the differences between the total score level was used Mann-Whitney $U$ test, to analysis of the differences between levels of substances in the frequency distribution Chi-square (Chisquare) test was used. According to the findings in the study there is no significant difference between the level of entrepreneurship of the Department of Recreation and Sport Management students. In addition, there is no significant difference according to gender and age entrepreneurship level. There is a significant difference between entrepreneurship levels according to practices that Recreation and Sport Management Department students have made and the courses that Recreation and Sport Management Department students have taken.
\end{abstract}

Keywords: College Students; Entrepreneurship level; Recreation; Sports Management

\section{Introduction}

The main purpose of this study is to determine the differences between the entrepreneurship levels of the fourth-year students who are receive dedication in the Sport Management and Recreation programs of universities.

The universe of this research is 4324 th class students that continuing their education in the Department of Recreation and Sport Management of Physical Education and Sports School and Sports Science Faculty. The sample of the study is 120 girls and 148 men; at total 268 fourth grade students that studying at Physical Education School of Akdeniz University, Kocaeli University, Sttk1 Kocman University, Sakarya University, Erciyes University and Sports Science School of Pamukkale University Departments of Recreation and Sports Management in the year of 2014 2015 fall semester.

\section{Method}

At the research, "Entrepreneurship Scale for the University Students" developed by Yilmaz and Sünbül (2009) is used University of Recreation and Sport Management to determine the level

\footnotetext{
${ }^{1}$ Mehmet Akif Ersoy University, BURDUR/TURKEY, ozmen cigdem@windowslive.com

${ }^{2}$ Asst. Prof. Dr., Mehmet Akif Ersoy University, BURDUR/TURKEY, odalkiran@mehmetakif.edu.tr
} 
Bacak, Ç., Dalkıran, O. (2016). A study for the evaluation of entrepreneurship level of fourth grade students in Recreation and Sports Management Department. International Journal of Social Sciences and Education Research, 2 (1), 45-49.

of fourth grade students in the Department of entrepreneurship. Students created by the researchers to determine the demographic features of "Personal Information Form" is used.

Entrepreneurship Scale for the University Students is a five point Likert scale consisting of 36 questions. Entrepreneurship points range between 36 and 180 points. The points between 36 and 64 are taken as extra low entrepreneurship, $93-123$ are taken as intermediate entrepreneurship, $124-151$ are taken as high entrepreneurship, $152-180$ are taken as very high entrepreneurship (Yılmaz and Sünbül, 2009).

Reliability co-efficient of Entrepreneurship Scale for the University Students was determined as .90. On the ground that each of the 36 articles of entrepreneurship scale provided a consistent result with each of them as well as total points of the scale, factor analysis was applied to all articles. Cronbach's alpha internal consistency co-efficient of scale used for the research was found as .92 and it was accepted as a consistent scale for the sample group (Y1lmaz and Sünbül, 2009).

SPSS 22 package program was used for data analysis and alpha value was regarded as 0.05 for statistical significance level. Frequency and percentage distribution was used for data analysis of personal information form.

\section{Results}

The research results revealed that there was not a significant difference between entrepreneurship levels based on department variable of the students studying on Recreation and Sports Management and their entrepreneurship levels are "High Entrepreneurship" ( $\mathrm{U}=8587,50, \mathrm{P}>.05)$. Therefore, having high-level entrepreneurship can be explained with the fact that the study fields and aims of the Departments of Recreation and Sports Managements are similar. According to the research carried out by Yelkikalan (2010), entrepreneurship course at universities should be compulsory not only for the Departments of Management but also for all departments and entrepreneurship course should be added to syllabuses. Furthermore, as the significance of entrepreneurship education for all of the departments at Universities in Turkey has been recognized, the deficiencies compared to the world should be overcome and it should be restored as a more unique and functional structure. This result increases the significance of the study carried out and also supports the research. Based on gender variable of the students studying on Recreation and Sports Management, it was found out that there was not a significant difference between their entrepreneurship levels $(\mathrm{U}=8587,50, \mathrm{P}>.05)$. Despite this result, it was found out that when the mean ranks of entrepreneurship levels are taken into consideration, women $(141,94)$ have "higher entrepreneurship levels" than men $(128,47)$. Although still some research findings in literature do not tally with the research result, it is seen that it supports that finding in general. Despite the fact that mean values of the research made by Cansiz (2007) are close to each other, it is found out that entrepreneurship levels of girls are higher than boys.

It was not found out in similar studies supporting the research findings that there was a significant difference between entrepreneurship level and gender variable (Kayalar and Ömürbek, 2007; Kılıç and at all.,2012). 
Bacak, C.., Dalkıran, O. (2016). A study for the evaluation of entrepreneurship level of fourth grade students in Recreation and Sports Management Department. International Journal of Social Sciences and Education Research, 2 (1), 45-49.

According to the internship variable of the students studying at the departments of Recreation and Sports Management and course variable of the students, it is found out that there is a significant difference between entrepreneurship levels $(\mathrm{U}=5280,50, \mathrm{P}<.05)$. When mean ranks are taken into consideration, entrepreneurship levels of the students who have completed their internships $(147,14)$ are higher than the others who have not completed their internship $(105,36)$. According to this result, it can be said that internship has a positive effect on entrepreneurship.

In their studies that are parallel to our study findings, Bozkurt and Alparslan (2013) emphasized that courses should be definitely practical for entrepreneurs and they should be invited to courses or conferences and asked to share their experiences, and they suggested that the students should be encouraged and theoretical information should be less important than practical information. According to the result of the same study they stated that students should be guided according to their interests earlier and within the scope of projects and indicated that university course context should be changed, improved and made more interactive through practice.

Thus, in the similar studies which are specified in literature and support the research findings, it is indicated that practical activities have a greater effect on entrepreneurship level than the other theoretical courses Bozkurt, 2007; İrmiş and Barutçu, 2012; Balaban and Özdemir, 2008; Güney and Nurmakhamatuly, 2007; Örücü and others, 2007; Özdemir and Mazgal, 2012; Durak, 2011; Ören and Biçkes, 2011; Korkmaz, 2012 (Bozkurt and Alparslan 2013).

Based on the research findings, it is found out that there is a significant difference on entrepreneurship levels of the students according to the Recreation Management course taken by the students from Recreation and Sports Management department $(\mathrm{U}=6856,00, \mathrm{P}<.05)$. When the mean ranks are taken into consideration, entrepreneurship levels of the students attending $(150,44)$ Recreation Management course are higher than the students not attending the course $(124,55)$. Based on this result, it can be said that Recreation Management course has an effect on increase of entrepreneurship levels.

According to the Management and Organization Course taken by the students from Recreation and Sports Management department, it is determined that there is significant difference between entrepreneurship levels of the students $(\mathrm{U}=4554,00, \mathrm{P}<, 05)$. When mean ranks are taken into consideration, entrepreneurship levels of the students attending the Management and Organization course (142.21) are higher than the others not attending the course (107,19). Based on this result, it can be said that Management and Organization course has an effect on increase of entrepreneurship level.

It is determined that there is a significant difference between entrepreneurship levels of the students according to the Fields of Application course taken by the students from Recreation and Sport Management department $(\mathrm{U}=5930,00, \mathrm{P}<.05)$. When the mean ranks are taken into consideration, entrepreneurship levels of the students taking the Management and Organization course (159.48) are higher than the others not taking the course (116.01). Based on this result, it can be said that Field of Application course has an effect on increase of entrepreneurship level.

In a similar study carried out by Koçyiğit (2013) on 250 university students, it was determined that course variable had a positive effect on entrepreneurship level. Therefore it can be said that positive effect of course variable on entrepreneurship level is a compatible result with literature. 
Bacak, Ç., Dalkıran, O. (2016). A study for the evaluation of entrepreneurship level of fourth grade students in Recreation and Sports Management Department. International Journal of Social Sciences and Education Research, 2 (1), 45-49.

It was observed in a research that education received by university students is generally a determinant on setting on their own businesses. Again in a similar study carried out by Koçyiğit (2013) on 250 university students, it was determined that course variable has a positive effect on entrepreneurship level. Therefore it can be said that positive effect of course variable on entrepreneurship level is compatible with the literature.

According to Sport Management $(\mathrm{U}=8141,50, \mathrm{P}>.05)$, Facility Management $(\mathrm{U}=8903,00$, $\mathrm{P}>.05)$, and Entrepreneurship $(\mathrm{U}=7442,00, \mathrm{P}>.05)$ courses taken by the students from Recreation and Sports Management department, no significant difference was determined between entrepreneurship levels of the students.

When research findings in literature were analyzed, it was stated that taking entrepreneurship course by the university students did not have any effect on entrepreneurship levels (Doğaner and Altunoğlu, 2010). However, in another study approximately $60 \%$ of the students from Kirghizstan and Uzbekistan, $42 \%$ of the students from Azerbaijan stated that they were taking entrepreneurship courses but this rate was about 29\% in Turkey (Abdullaeva, 2007). Within this scope, inadequacy of course variety on entrepreneurship and inadequacy of the current course content and course activity are considered as main reasons of different results of the researches and studies in literature.

According to the research findings, when the energy sensation that leads a person to different jobs was analyzed, while the students from sports management expressed a positive opinion at the rates of $39 \%$ (very often) and $47.8 \%$ (frequently), this rate dropped to $31.8 \%$ (very often) and $40.9 \%$ (frequently) for students from Recreation Department. According to this result, it was determined that the difference on sensation between the students from sports management and the students from recreation department was found to be significant $\left(\chi^{2}=9,80, p<.05\right)$. Although it was determined from the scale items that there was a significant difference in the energy sensation that leads a person to different jobs according to the department variable, when the positive thoughts are considered it can be said that students from Sports Management (86\%) and students from Recreation Department (71\%) on entrepreneurship have positive perception.

The analysis of perception about projects that lead a person to new experiences according to the department variable revealed that the students of recreation department stated positive thoughts at the rates of $37.1 \%$ (very often) and $46.2 \%$ (frequently) while these rates dropped to $30.9 \%$ (very often) and $41.9 \%$ (frequently) for the students of sports management. According to that result, the difference observed at the perception levels of the students of Recreation Department and the students of Sports Management was found to be significant

$\left(\chi^{2}=8,42, \mathrm{p}<.05\right)$. Though the scale items revealed a significant difference on the perception of feeling the energy to work on projects that lead new experiences according to the department variable, it can be said that perceptions of the students of Sports Management (83\%) and students of Recreation Department (71\%) on entrepreneurship are high when the positive thoughts percentages are taken into consideration.

\section{Conclusion}

Consequently, it was determined that entrepreneurship levels of the students from Recreation and Sports Management Departments were similar because of the similarity of study fields and 
Bacak, Ç., Dalkıran, O. (2016). A study for the evaluation of entrepreneurship level of fourth grade students in Recreation and Sports Management Department. International Journal of Social Sciences and Education Research, 2 (1), 45-49.

goals. Even though girls' entrepreneurship levels are higher than the boys' entrepreneurship levels in terms of gender variables, it does not have any importance. According to the research results aiming to determine the factors affecting entrepreneurship levels of the students, it was determined that internship related to the education received and some department course taken had a significant and positive effect on the students' entrepreneurship levels. It can be expressed that research findings show parallelism with many of the research results in the literature. Therefore, arranging the variety and period of the fields of application as well as arranging the course variety and course content in curriculum have a significant role in increasing the entrepreneurship levels of the students from recreation and sports management department.

\section{Reference}

Abdullaev, F. (2007). Entrepreneurship and Business Value of Student Characteristics: Kyrgyzstan, Uzbekistan, Azerbaijan and Turkey Comparison, Institute of Social Sciences, published PhD, Sakarya University, Sakarya

Bozkurt, Ç. Ö., Alparslan, A.M., (2013). Finding Entrepreneurs Needed Features in entrepreneurship education and student feedback, Entrepreneurship and Development Magazine, 8. 1-3

Cansiz E. (2007). Determining the entrepreneurial characteristics of university students, Suleyman Demirel University, Case Institute of Social Sciences, published M.Sc., Isparta.

Doğaner, M., Altunoğlu, A. E., (2010). Nazilli Adnan Menderes University Faculty of Economics department of entrepreneurship orientation of students. Nazilli Adnan Menderes University Faculty of Economics, Journal of Organization and Management Sciences, 2, 2-3

Kayalar, M. , Ömürbek, N. (2007) Examining the gender context of risk-taking entrepreneurs property Factor candidate, Journal of Economics and Administrative Sciences, 21, 185-200

Kılıç, R., Keklik, B., (2012). A Study on Trends of University Students Entrepreneurship: The Case of Banda Department of Business Administration, Süleyman Demirel University Faculty of Economics Journal, 2, 424-426

Koçyiğit, E. (2013). Determination of the entrepreneurial characteristics of university students, Arel University, M.Sc., Istanbul,

Yılmaz, E. , Sünbül, A.M. (2009). Towards the Development of Entrepreneurial University Students Scale, Selcuk University Journal of the Institute of Social Sciences, 21, 195-203

Yelkikalan,Y., Karadeniz, Y., Akatay, A., Köse, C., Yıldırım H. M., Özer., (2010), Scale Entrepreneurship in Turkey and the World Universities: A Comparative Example KMÜ Journal of Social and Economic Studies, 12, 51-59 